\title{
THE REVIEW OF ECOLOGICAL AND GENETIC RESEARCH OF PONTO-CASPIAN GOBIES (Pisces, Gobiidae) IN EUROPE
}

\author{
Goran Jakšić1, *, Margita Jadan², Marina Piria
}

${ }^{1}$ City of Karlovac, Banjavčičeva 9, 47000 Karlovac, Croatia

${ }^{2}$ Division of materials chemistry, Ruđer Bošković Institute, Bijenička 54, 10000 Zagreb, Croatia

${ }^{3}$ University of Zagreb, Faculty of Agriculture, Department of Fisheries, Beekeeping, Game management and Special Zoology, Svetošimunska 25, 10000 Zagreb, Croatia

*Corresponding Author, Email: goran.jaksic@karlovac.hr

\section{ARTICLE INFO}

Received: 27 January 2016

Received in revised form: 14 May 2016

Accepted: 20 May 2016

Available online: 24 May 2016

\begin{abstract}
Invasive Ponto-Caspian gobies (monkey goby Neogobius fluviatilis, round goby Neogobius melanostomus and bighead goby Ponticola kessleri) have recently caused dramatic changes in fish assemblage structure throughout European river systems. This review provides summary of recent research on their dietary habits, age and growth, phylogenetic lineages and gene diversity. The principal food of all three species is invertebrates, and more rarely fish, which depends on the type of habitat, part of the year, as well as the morphological characteristics of species. According to the von Bertalanffy growth model, size at age is specific for the region, but due to its disadvantages it is necessary to test other growth models. Phylogenetic analysis of monkey goby and round goby indicates separation between the Black Sea and the Caspian Sea haplotypes. The greatest genetic diversity is found among populations of the Black Sea, and the lowest among European invaders. The lack of molecular research on bighead goby requires further studies.
\end{abstract}

Jakšić, G., Jadan, M., Piria, M. (2016): The review of ecological and genetic research of Ponto-Caspian gobies (Pisces, Gobiidae) in Europe. Croatian Journal of Fisheries, 74, 110-123. DOI: 10.1515/cjf-2016-0015.

\section{INTRODUCTION}

In the last few decades, Ponto-Caspian gobies (P-C gobies) - monkey goby Neogobius fluviatilis (Pallas, 1814), round goby Neogobius melanostomus (Pallas, 1814) and bighead goby Ponticola kessleri (Günther, 1861) - were transported from their natural habitat by ships to the main European ports and then migrated into the majority of European inland waters (Jazdzewski and Konopacka, 2002; Corkum et al., 2004; Copp et al., 2005; Polačik et al., 2008; Leuven et al., 2009; Manné et al., 2013; Povž, 2016). It has been suggested that increased annual water temperature
(Bonacci et al. 2008) or pressure of anthropogenic stressors contributed to their success in expanding distribution (Copp et al., 2005; Wiesner, 2005; Harka and Bíró, 2007). P-C gobies have shown a relatively high invasive potential in the Balkan countries (Simonovic et al., 2013), as well as a medium high and high invasive potential in Croatia (Piria et al., 2016a). Each of these species has its own particularities regarding its habitat requirements and can survive in both, the gravel-sand and rocky bottom (Kessel van et al., 2011; Kottelat and Freyhof, 2007). They live up to five years (Kottelat and Freyhof, 2007), growing to a maximum standard length of 220 mm (Erös et al., 2005; Bogut et al., 
2006; Vassilev et al., 2012) and feed mostly on invertebrates (Adamek et al., 2007; Piria et al., 2016b). Molecular analyses of round goby have shown increase in the genetic diversity of round goby due to the passive transportation of larvae to new habitats caused by different currents. In this way, genes from distant populations are transmitted (Kocovsky et al., 2011). The genetic diversity is, therefore, increased by ship transportation during which juveniles are transported into ballast water (Brown and Stepien, 2008), making the populations more similar than when the transmission of genes is caused by natural or biological mechanisms (LaRue et al., 2011). Several review papers are related to biology, distribution and ecological implications on $\mathrm{P}-\mathrm{C}$ gobies (Vanderploeg et al., 2002; Kornis et al., 2012; Roche et al., 2013), but there is not a single comprehensive review on their natural diet, growth or genetic characteristics in native and non-native distribution.

Thus, the aim of this study is to give a review of ecological and genetic research of monkey goby, round goby and bighead goby in European inland waters. The specific aims are: (1) to review diet, age and growth of the three species of Ponto-Caspian gobies in their native and non-native habitats; (2) to discuss phylogenetic lineages and genetic diversity of Ponto-Caspian gobies in the areas of native and non-native habitats; and (3) to discuss their potential impact on native fish species.

\section{STUDY AREA}

The freshwater area of Eastern and South-Eastern Europe is divided into the Black, Caspian and Azov Sea, Lake Manyas, Sasyk Lagoon and Simferopol Reservoir, as well as the lower Danube, Dnieper, Dniester, Don, Volga and Moscow. The freshwater area of Central Europe covers the Baltic Sea, the Vistula, Hron, Ipel', middle and upper Danube, Sava and Rhine, and also Western Europe covers the Albert and GentTerneuzen Canals in the Rhine River Basin.

\section{ORIGIN}

Monkey goby was first registered in the Danube in 1960 (Bănărescu, 1970). Its upstream expansion was recorded in the Romanian/Bulgarian section (Smirnov, 1986), Hungary (Ahnelt et al., 1998), Slovakia (Jurajda et al., 2005) and in the Sava in Croatia (Ćaleta, 2007). Round goby was recorded in the Danube in Serbia (Simonovic et al., 1998), Slovakia (Adamek et al., 2007), Croatia (Mustafić, 2005). Hungary (Erös et al., 2005), in the Sava in Croatia (Piria et al., 2011b), in the Rhine River Basin in Belgium (Verreycken et al., 2011) and Switzerland (Kalchhauser et al., 2013), and in the Baltic Sea (Sapota, 2004). In 1910, the first individuals of bighead goby were caught in the Danube in Serbia (Vutskits, 1911). Also, it was recorded in the Danube in Hungary (Erös et al., 2005), Croatia and Slovakia (Polačik et al., 2008), Germany
(Seifert and Hartmann, 2000) and in the Rhine in Germany (Borcherding et al., 2011) and Switzerland (Kalchhauser et al., 2013).

\section{DIET}

\section{Dietary items}

Research on monkey goby diet in the non-native area of Europe, in the Vistula in Poland (Kakareko et al., 2005; Grabowska et al., 2009), the Sava in Croatia (Piria et al., 2011a), the Danube and the Hron in Slovakia (Adámek et al., 2007), indicates that its preferred diet is Chironomidae, Trichoptera and Amphipoda. Additionally, important nutritional taxa were Bivalvia and Odonata (Piria et al., 2016b). Round goby in the Danube River in Serbia and in its tributary, the Sava River in Croatia, feeds mostly on Bivalvia (Simonović et al., 1998, 2001; Piria et al., 2016b), however, in the Danube River in Slovakia (Števove and Kováč, 2013), Germany (Brandner et al., 2013) and Hungary (Borza et al., 2009) on Diptera (Chironomidae) and alien Ponto Caspian Amphipoda (Dikerogammarus sp.). The principal food of bighead goby is Amphipods and small fishes (Adámek et al., 2007; Piria et al., 2016b). In an area invaded by Dikerogammarus sp., C. curvispinum and Asian molluscs C. fluminea (Ponto-Caspian invertebrates), most of the research reveals positive selection for these species (Adámek et al., 2007; Borza et al., 2009; Brander et al., 2013b). These preferences represent one of the possible solutions to the problem of invertebrate invaders which are still expanding their distribution (Žganec et al., 2009; Paunović et al., 2012). The preferred diet of monkey goby in the native area consists of Bivalvia (Sindilariu and Freyhof, 2003; Pinchuk et al., 2003) in the Danube Delta. Round goby in the Azov Sea feeds mostly on Polychaeta (Svietovidov, 1964), and in the Black Sea in Romania on Bivalvia and Gastropoda (Bănaru and Harmelin-Vivien, 2009). Bighead goby in the Dniester estuary (Vasil'Eva and Vasil'Ev, 2003) and the lower Danube (Polačik et al., 2009) feeds mostly on Amphipoda and Pisces.

List of dietary items found in non-native and native habitat for all three $\mathrm{P}-\mathrm{C}$ gobies are presented in Table 1 with a note on preferred taxa.

\section{Diet overlap between P-C gobies and other fish species}

Significant overlap in the diet between monkey goby and round goby from the Sava River in Croatia was recorded (Piria et al., 2016b). However, bighead goby and round goby diets did not overlap in the Sava (Piria et al., 2016b), contrary to the findings of Števove and Kováč (2013). Another research conducted in Hungary found that 
Table 1. Taxa found in the diet of monkey goby, round goby and bighead goby in their non-native and native habitat [+, presence of dietary item; p, preferred item; n.d., not determined; $a=e=m$, Danube Slovakia; b, Sava River Basin; $c=g$, Vistula Poland; d, Sava Croatia; f, Danube Hungary; h, Danube Serbia; i=k, Baltic Sea Gdansk; j, Baltic Sea Denmark; I, laboratory studies; n, Danube Germany; o, Rhine Germany; p, Danube Danube Delta; q, Lake Razelm Danube Delta; r, Dnieper estuary; s, Black and Azov Sea Basin; t=u, Azov Sea; v, Black Sea Romania; z, Dniester estuary; x, lower Danube; y, Bug, Grigoryevskiy, Dnieper and Azov Utlukskiy estuary; 1, Adámek et al. (2007); 2 , Piria et al. (2016b); 3, Grabowska et al. (2007); 4, Piria et al. (2011a); 5, Števove and Kováč (2013); 6, Borza et al. (2009); 7, Kakareko et al. (2005); 8, Simonović et al. (2001); 9, Karlson et al. (2007); 10, Azour 2011; 11, Skóra and Rzeznik (2001); 12, Chotkowski and Marsden (1999); 13, Copp et al. (2008); 14, Brandner et al. (2013); 15, Borcherding et al. (2013); 16, Sindilariu and Freyhof (2003); 17, Pinchuk et al. (2003); 18, Smirnov 1986; 19, Svietovidov 1964; 20, Kovtun et al. (1974); 21, Bănaru and Harmelin-Vivien (2009); 22, Vasil'Eva and Vasil'Ev (2003); 23, Polačik et al. (2009)]

\begin{tabular}{|c|c|c|c|c|c|}
\hline Dietary item & Monkey goby & Round goby & Bighead goby & Sampling location & References \\
\hline \multicolumn{6}{|l|}{ Non-native habitat } \\
\hline \multicolumn{6}{|l|}{ Trichoptera } \\
\hline Brachycentridae & & & $+^{5}$ & $e^{5}$ & 5 \\
\hline Brachycentrus subnubilus & & & $+^{1}$ & $a^{1}$ & 1 \\
\hline Goeridae & & $+^{5}$ & & $\mathrm{e}^{5}$ & 5 \\
\hline Hydropsychidae & & $+^{5}$ & $+^{5}$ & $e^{5}$ & 5 \\
\hline Hydropsyche sp. & $+^{1}$ & $t^{6}$ & $+1,6$ & $a^{1} f^{6}$ & 1,6 \\
\hline H. angustipennis & $+^{4}$ & & & $d^{4}$ & 4 \\
\hline Hydroptilidae & & $t^{5}$ & $+^{5}$ & $e^{5}$ & 5 \\
\hline Hydroptila sparsa & & & $+^{1}$ & $a^{1}$ & 1 \\
\hline Limnephilidae & & $+^{5}$ & & $e^{5}$ & 5 \\
\hline Polycentropodidae & & $+^{5}$ & & $e^{5}$ & 5 \\
\hline Sericostoma sp. & & $t^{5}$ & & $e^{5}$ & 5 \\
\hline Leptoceridae & & & $+^{1}$ & $a^{1}$ & 1 \\
\hline Trichoptera n.d. & $+^{2,3,7} p$ & $t^{2,14}$ & $t^{2,5,14}$ & $b^{2}, c^{3}, e^{5}, g^{7}, n^{14}$ & $2,3,5,7,14$ \\
\hline \multicolumn{6}{|l|}{ Ephemeroptera } \\
\hline Baetidae & & $+^{5}$ & $t^{5}$ & $e^{5}$ & 5 \\
\hline Caenidae & & $t^{5}$ & $t^{5}$ & $e^{5}$ & 5 \\
\hline Heptageniidae & & & $+^{1}$ & $a^{1}$ & 1 \\
\hline Caenis sp. & $+^{1}$ & & $+^{1}$ & $a^{1}$ & 1 \\
\hline Baetis sp. & & & $+^{1}$ & $a^{1}$ & 1 \\
\hline P. luteus & $+^{1}$ & $t^{5}$ & $\boldsymbol{+}^{1,5}$ & $a^{1}, e^{5}$ & 1,5 \\
\hline Ephoron virgo & $+^{1}$ & & $+^{1}$ & $a^{1}$ & 1 \\
\hline Oecetis albicorne & $+^{1}$ & & & $a^{1}$ & 1 \\
\hline Ephemeroptera n.d. & $t^{3}$ & $\boldsymbol{t}^{6,14}$ & $\boldsymbol{t}^{5,6,14}$ & $c^{3}, e^{5}, f^{6}, n^{14}$ & $3,5,6,14$ \\
\hline \multicolumn{6}{|l|}{ Plecoptera } \\
\hline Plecoptera n.d. & & $\boldsymbol{+}^{8,14}$ & $+^{14}$ & $h^{8}, n^{14}$ & 8,14 \\
\hline \multicolumn{6}{|l|}{ Odonata } \\
\hline Zygoptera & $t^{3}$ & & & $c^{3}$ & 3 \\
\hline Coenagrionidae & & & $+^{5}$ & $\mathrm{e}^{5}$ & 5 \\
\hline Gomphidae & & & $+^{5}$ & $e^{5}$ & 5 \\
\hline Odonata n.d. & $t^{2}$ & & & $b^{2}$ & 2 \\
\hline \multicolumn{6}{|l|}{ Heteroptera } \\
\hline Aphelocheirus aestivalis & & & $+^{1}$ & $a^{1}$ & 1 \\
\hline Micronecta sp. & & $t^{5}$ & $t^{5}$ & $e^{5}$ & 5 \\
\hline Heteroptera n.d. & & $+^{6}$ & $+^{5}$ & $e^{5}, f^{6}$ & 5,6 \\
\hline \multicolumn{6}{|l|}{ Coleoptera } \\
\hline Dytiscidae & & $+^{5}$ & $t^{5}$ & $e^{5}$ & 5 \\
\hline Dytiscus sp. & & $+^{5}$ & $+^{5}$ & $e^{5}$ & 5 \\
\hline Elmidae & & $+^{5}$ & $+^{5}$ & $\mathrm{e}^{5}$ & 5 \\
\hline
\end{tabular}


Table 1. Continued

\begin{tabular}{|c|c|c|c|c|c|}
\hline Hydraenidae & & $++^{5}$ & & $\mathrm{e}^{5}$ & 5 \\
\hline Coleoptera n.d. & $t^{2,3}$ & $t^{2}$ & & $b^{2}, c^{3}$ & 2,3 \\
\hline \multicolumn{6}{|l|}{ Diptera } \\
\hline Chironomidae & $t^{1,2,3,4,7,15} p$ & $\boldsymbol{+}^{1,2,5,13,14,15} \mathrm{p}$ & $t^{1,5,13,14,15} p$ & $a^{1}, b^{2}, c^{3}, d^{4}, e^{5}, g^{7}, m^{13}, n^{14}, o^{15}$ & $1,2,3,4,5,7,13,14,15$ \\
\hline Chironomus sp. & $+^{7}$ & & & $g^{7}$ & 7 \\
\hline Cladotanytarsus sp. & $+^{7}$ & & & $g^{7}$ & 7 \\
\hline Cricotopus sp. & $+^{7}$ & & & $g^{7}$ & 7 \\
\hline Dicrotendipes sp. & $+^{7}$ & & & $g^{7}$ & 7 \\
\hline Glyptotendipes sp. & $+^{7}$ & & & $g^{7}$ & 7 \\
\hline Polypedilum sp. & $+^{7}$ & & & $g^{7}$ & 7 \\
\hline Tanytarsus sp. & $+^{7}$ & & & $g^{7}$ & 7 \\
\hline Cryptochironomus sp. & $+^{7}$ & & & $g^{7}$ & 7 \\
\hline Simuliidae & $t^{3}$ & $t^{5}$ & $t^{5}$ & $c^{3}, e^{5}$ & 3,5 \\
\hline Tipulidae & $t^{2,3}$ & & $t^{2}$ & $b^{2}, c^{3}$ & 2,3 \\
\hline Ceratopogonidae & $t^{3}$ & $t^{5}$ & $+^{1,5}$ & $a^{1}, c^{3}, e^{5}$ & $1,3,5$ \\
\hline Ephydridae & & $t^{5}$ & & $e^{5}$ & 5 \\
\hline Limoniidae & & $+^{5}$ & $+^{5}$ & $e^{5}$ & 5 \\
\hline Psychoda sp. & & $t^{5}$ & & $e^{5}$ & 5 \\
\hline Syrphidae & & $t^{5}$ & $t^{5}$ & $e^{5}$ & 5 \\
\hline Diptera n.d. & $t^{3,7}$ & $\boldsymbol{t}^{5,8}$ & & $c^{3}, e^{5}, g^{7}, h^{8}$ & $3,5,7,8$ \\
\hline \multicolumn{6}{|l|}{ Ostracoda } \\
\hline Ostracoda n.d. & $+^{1,3,7}$ & $t^{5,6}$ & $\mathbf{t}^{5,6}$ & $a^{1}, c^{3}, e^{5}, f^{6}, g^{7}$ & $1,3,5,6,7$ \\
\hline \multicolumn{6}{|l|}{ Turbellaria } \\
\hline Turbellaria n.d. & & $t^{5}$ & $t^{5}$ & $e^{5}$ & 5 \\
\hline \multicolumn{6}{|l|}{ Bryozoa } \\
\hline Bryozoa n.d. & & $+^{5,6,14}$ & $\boldsymbol{t}^{5}$ & $e^{5}, f^{6}, n^{14}$ & $5,6,14$ \\
\hline \multicolumn{6}{|l|}{ Copepoda } \\
\hline Copepoda n.d. & $+^{3,7}$ & $\boldsymbol{t}^{1,5}$ & $t^{5}$ & $a^{1}, c^{3}, e^{5}, g^{7}$ & $1,3,5,7$ \\
\hline \multicolumn{6}{|l|}{ Rotatoria } \\
\hline Rotatoria n.d. & $+^{7}$ & & & $g^{7}$ & 7 \\
\hline \multicolumn{6}{|l|}{ Gastropoda } \\
\hline Potamopyrgus sp. & $\boldsymbol{+}^{7}$ & $t^{5}$ & $t^{5}$ & $e^{5}, g^{7}$ & 5,7 \\
\hline Viviparus sp. & & & $t^{5}$ & $e^{5}$ & 5 \\
\hline Gastropoda n.d. & $t^{2,3,7} \mathrm{p}$ & $t^{2,5,9,10,11} \mathrm{p}$ & & $b^{2}, c^{3}, e^{5}, g^{7}, i^{9}, j^{10}, k^{11}$ & $2,3,5,7,9,10,11$ \\
\hline L. peregra & & $t^{8}$ & & $\mathrm{~h}^{8}$ & 8 \\
\hline T. danubialis & & $t^{8}$ & & $h^{8}$ & 8 \\
\hline T. fluviatilis & & $t^{6}$ & & $f^{6}$ & 6 \\
\hline L. naticoides & & $t^{6}$ & & $f^{6}$ & 6 \\
\hline Eggs & & & $t^{5}$ & $e^{5}$ & 5 \\
\hline \multicolumn{6}{|l|}{ Bivalvia } \\
\hline Sphaeriidae & $t^{7}$ & $+^{6,8} \mathrm{p}$ & & $f^{6}, g^{7}, h^{8}$ & $6,7,8$ \\
\hline D. polymorpha & $+^{7}$ & $+^{6,8}$ & & $f^{6}, g^{7}, h^{8}$ & $6,7,8$ \\
\hline Unionidae & & $+^{6,8} \mathrm{p}$ & & $f^{6}, h^{8}$ & 6,8 \\
\hline C. fluminea & & $++^{6} \mathrm{p}$ & & $f^{6}$ & 6 \\
\hline Anodonta sp. & & $+^{8}$ & & $h^{8}$ & 8 \\
\hline Bithyniidae & & $t^{5}$ & & $e^{5}$ & 5 \\
\hline Pisidium sp. & $+^{1,7}$ & $+^{5,8}$ & $t^{5}$ & $a^{1}, e^{5}, g^{7}, h^{8}$ & $1,5,7,8$ \\
\hline Sphaerium sp. & $+^{7}$ & $t^{5}$ & & $e^{5}, g^{7}$ & 5,7 \\
\hline Sphaeriidae n.d. & $+^{7}$ & & & $g^{7}$ & 7 \\
\hline Valvata sp. & & $t^{5}$ & & $\mathrm{e}^{5}$ & 5 \\
\hline Bivalvia n.d. & $t^{2}$ & $t^{2,5,9,10,11}$ & & $b^{2}, e^{5}, i^{9}, j^{10}, k^{11}$ & $2,5,9,10,11$ \\
\hline \multicolumn{6}{|l|}{ Polychaeta } \\
\hline Hypania invalida & & $+^{5}$ & $t^{5}$ & $e^{5}$ & 5 \\
\hline Polychaeta n.d. & & $\boldsymbol{t}^{9,11}$ & & $\mathrm{i}^{9}, \mathrm{k}^{11}$ & 9,11 \\
\hline
\end{tabular}


Table 1. Continued

\begin{tabular}{|c|c|c|c|c|c|}
\hline \multicolumn{6}{|l|}{ Oligochaeta } \\
\hline Lumbricidae & $+^{1}$ & & & $a^{1}$ & 1 \\
\hline Oligochaeta n.d. & $+^{2,3,7}$ & $\boldsymbol{t}^{2,5,6,8,14}$ & $\boldsymbol{t}^{5,14}$ & $b^{2}, c^{3}, e^{5}, f^{6}, g^{7}, h^{8}, n^{14}$ & $2,3,5,6,7,8,14$ \\
\hline \multicolumn{6}{|l|}{ Hirudinea } \\
\hline Erpobdella sp. & & & $+^{1}$ & $a^{1}$ & 1 \\
\hline Hirudinea n.d. & $t^{3,7}$ & $t^{6}$ & $+^{5,6}$ & $c^{3}, e^{5}, f^{6}, g^{7}$ & $3,5,6,7$ \\
\hline \multicolumn{6}{|l|}{ Nematomorpha } \\
\hline Nematomorpha n.d. & & $t^{5}$ & $t^{5}$ & $e^{5}$ & 5 \\
\hline \multicolumn{6}{|l|}{ Hydracarina } \\
\hline Hydracarina n.d. & & $\boldsymbol{+}^{1,5,6}$ & $\boldsymbol{+}^{5}$ & $a^{1}, e^{5}, f^{6}$ & $1,5,6$ \\
\hline \multicolumn{6}{|l|}{ Cladocera } \\
\hline Daphniasp. & & & $+^{1}$ & $a^{1}$ & 1 \\
\hline Cladocera n.d. & $t^{3,7}$ & $\boldsymbol{t}^{5,6}$ & $\boldsymbol{+}^{5}$ & $c^{3}, e^{5}, f^{6}, g^{7}$ & $3,5,6,7$ \\
\hline \multicolumn{6}{|l|}{ Nematoda } \\
\hline Nematoda n.d. & $+^{1}$ & & & $a^{1}$ & 1 \\
\hline \multicolumn{6}{|l|}{ Ostracoda } \\
\hline Ostracoda n.d. & $+^{1,3,7}$ & $t^{5,6}$ & $+^{5,6}$ & $a^{1}, c^{3}, e^{5}, f^{6}, g^{7}$ & $1,3,5,6,7$ \\
\hline \multicolumn{6}{|l|}{ Copepoda } \\
\hline Copepoda n.d. & $+^{3,7}$ & $+^{1,5}$ & $+^{5}$ & $a^{1}, c^{3}, e^{5}, g^{7}$ & $1,3,5,7$ \\
\hline \multicolumn{6}{|l|}{ Isopoda } \\
\hline Jaera istri & & $\boldsymbol{t}^{5,6}$ & $+^{5,6}$ & $e^{5}, f^{6}$ & 5,6 \\
\hline Jaera sarsi & & $+^{14}$ & $+^{14}$ & $\mathrm{n}^{14}$ & 14 \\
\hline Isopoda n.d. & & $+{ }^{10,11}$ & & $\mathrm{j}^{10}, \mathrm{k}^{11}$ & 10,11 \\
\hline \multicolumn{6}{|l|}{ Amphipoda } \\
\hline P. robustoides & $t^{3}$ & & & $c^{3}$ & 3 \\
\hline D. haemobaphes & $t^{3}$ & & & $c^{3}$ & 3 \\
\hline Cheliochorophium sp. & & $+^{14}$ & $+^{14}$ & $\mathrm{n}^{14}$ & 14 \\
\hline C. curvispinum & $t^{3}$ & $t^{6}$ & $+^{1,6}$ & $a^{1}, c^{3}, f^{6}$ & $1,3,6$ \\
\hline Amphipoda n.d. & $+^{3,7} \mathrm{p}$ & $\boldsymbol{t}^{5,9,10,11}$ & $+^{5}$ & $c^{3}, e^{5}, g^{7}, i^{9}, j^{10}, k^{11}$ & $3,5,7,9,10,11$ \\
\hline Corophium sp. & & $t^{5}$ & $t^{5}$ & $e^{5}$ & 5 \\
\hline Gammaridae & & $++^{13}$ & $+^{13}$ & $\mathrm{~m}^{13}$ & 13 \\
\hline Dikerogammarus sp. & & $+^{5,6,14} \mathrm{p}$ & $\boldsymbol{t}^{5,6,14} \mathrm{p}$ & $e^{5}, f^{6}, n^{14}$ & $5,6,14$ \\
\hline Echinogammarus sp. & & $+^{14}$ & $t^{14}$ & $\mathrm{n}^{14}$ & 14 \\
\hline Pontogammarus sp. & & $+^{14}$ & $+^{14}$ & $\mathrm{n}^{14}$ & 14 \\
\hline Obesogammarus sp. & & $+^{14}$ & $+^{14}$ & $\mathrm{n}^{14}$ & 14 \\
\hline D. villosus & & $\mathbf{+}^{1}$ & $+^{1}$ & $a^{1}$ & 1 \\
\hline Gammarus sp. & $t^{2,4}$ & $t^{2,5,8}$ & $t^{2,5}$ & $b^{2}, d^{4}, e^{5}, h^{8}$ & $2,4,5,8$ \\
\hline Gammarus roeseli & & $+^{14}$ & $+^{14}$ & $\mathrm{n}^{14}$ & 14 \\
\hline O. obesus & & $+^{6}$ & $\mathbf{t}^{6}$ & $f^{6}$ & 6 \\
\hline E. ichnus & & $+^{6}$ & $\boldsymbol{t}^{6}$ & $f^{6}$ & 6 \\
\hline Niphargus sp. & & $+^{6}$ & & $f^{6}$ & 6 \\
\hline \multicolumn{6}{|l|}{ Mysida } \\
\hline Lymnomisis benedeni & & $t^{5}$ & $+^{5,6}$ & $e^{5}, f^{6}$ & 5,6 \\
\hline Mysida n.d. & & & $+^{14}$ & $\mathrm{n}^{14}$ & 14 \\
\hline \multicolumn{6}{|l|}{ Pisces } \\
\hline Cyprinidae & & & $t^{2,5,14}$ & $b^{2}, e^{5}, n^{14}$ & $2,5,14$ \\
\hline L. cephalus & & & $t^{2}$ & $b^{2}$ & 2 \\
\hline P. fluviatilis & & & $+^{14}$ & $\mathrm{n}^{14}$ & 14 \\
\hline S. lucioperca & & & $+^{1}$ & $a^{1}$ & 1 \\
\hline Z. zingel & & & $\mathbf{t}^{1}$ & $a^{1}$ & 1 \\
\hline Gymnocephalus sp. & & & $+^{5}$ & $e^{5}$ & 5 \\
\hline Gobiidae & $t^{2}$ & & $+^{2,5}$ & $b^{2}, e^{5}$ & 2,5 \\
\hline Neogobius sp. & & & $t^{5}$ & $e^{5}$ & 5 \\
\hline P. kessleri & & & $t^{5}$ & $e^{5}$ & 5 \\
\hline
\end{tabular}


Table 1. Continued

\begin{tabular}{|c|c|c|c|c|c|}
\hline N. melanostomus & & $t^{5}$ & $\boldsymbol{t}^{5,14}$ & $\mathrm{e}^{5}, \mathrm{n}^{14}$ & 5,14 \\
\hline P. semilunaris & & & $t^{5}$ & $e^{5}$ & 5 \\
\hline Eggs & & $\boldsymbol{t}^{5,6}$ & $+^{5}$ & $e^{5}, f^{6}$ & 5,6 \\
\hline Macrophytes & & $t^{5}$ & $t^{5}$ & $e^{5}$ & 5 \\
\hline Pisces n.d. & $+^{3,7}$ & $\boldsymbol{+}^{5,9,10}$ & $+^{1,2,5,6} \mathrm{p}$ & $a^{1}, b^{2}, c^{3}, e^{5}, f^{6}, g^{7}, i^{9}, j^{10}$ & $1,2,3,5,6,7,9,10$ \\
\hline S. namaycush & & $+^{12}$ & & $1^{12}$ & 12 \\
\hline A. fluvescens & & $+^{12}$ & & $1^{12}$ & 12 \\
\hline \multicolumn{6}{|l|}{ Terrestric Arthropoda } \\
\hline Linyphiidae & & $t^{5}$ & & $e^{5}$ & 5 \\
\hline Auchenorrhyncha & & $t^{5}$ & & $e^{5}$ & 5 \\
\hline Diplopoda & & $t^{5}$ & & $e^{5}$ & 5 \\
\hline Dipteran imagines & & $t^{5}$ & & $\mathrm{e}^{5}$ & 5 \\
\hline Chilopoda & & & $t^{5}$ & $e^{5}$ & 5 \\
\hline Thysanoptera & & $t^{5}$ & & $e^{5}$ & 5 \\
\hline Terrestric Arthropoda n.d. & & & $t^{5}$ & $e^{5}$ & 5 \\
\hline \multicolumn{6}{|l|}{ Terrestric Isopoda } \\
\hline Terrestric Isopoda n.d. & & $t^{6}$ & $+^{6}$ & $f^{6}$ & 6 \\
\hline \multicolumn{6}{|l|}{ Terrestric Hymenoptera } \\
\hline Terrestric Hymenoptera n.d. & & $t^{6}$ & $t^{6}$ & $f^{6}$ & 6 \\
\hline \multicolumn{6}{|l|}{ Native habitat } \\
\hline \multicolumn{6}{|l|}{ Bivalvia } \\
\hline Corbicula & $+^{16}$ & & & $\mathrm{p}^{16}$ & 16 \\
\hline D. polymorpha & $+{ }^{17} p$ & & & $q^{17}, r^{17}$ & 17 \\
\hline Bivalvia n.d. & & $+^{17,21} \mathrm{p}$ & & $v^{21}, y^{17}$ & 17,21 \\
\hline \multicolumn{6}{|l|}{ Gastropoda } \\
\hline Lithoglyphus & $++^{16}$ & & & $\mathrm{p}^{16}$ & 16 \\
\hline \multicolumn{6}{|l|}{ Isopoda } \\
\hline Isopoda n.d. & & $+^{21}$ & & $v^{21}$ & 21 \\
\hline \multicolumn{6}{|l|}{ Amphipoda } \\
\hline Cheliochorophium sp. & & $++^{17}$ & $+^{22}$ & $z^{22}, y^{17}$ & 17,22 \\
\hline Gammaridae & & $++^{17}$ & & $\mathrm{y}^{17}$ & 17 \\
\hline Amphipoda n.d. & $+^{18}$ & $t^{21}$ & $+^{22,23} \mathrm{p}$ & $\mathrm{s}^{18}, \mathrm{v}^{21}, \mathrm{z}^{22}, \mathrm{x}^{23}$ & $18,21,22,23$ \\
\hline \multicolumn{6}{|l|}{ Mysida } \\
\hline Mysida n.d. & & & $+^{22}$ & $\mathrm{z}^{22}$ & 22 \\
\hline \multicolumn{6}{|l|}{ Cirrhipoda } \\
\hline Cirrhipoda n.d. & & $+^{21}$ & & $v^{21}$ & 21 \\
\hline \multicolumn{6}{|l|}{ Trichoptera } \\
\hline Trichoptera n.d. & & $+^{21}$ & & $v^{21}$ & 21 \\
\hline \multicolumn{6}{|l|}{ Heteroptera } \\
\hline Corixidae & $+^{16}$ & & & $\mathrm{p}^{16}$ & 16 \\
\hline \multicolumn{6}{|l|}{ Diptera } \\
\hline Chironomidae & $+^{16,18}$ & $+^{17}$ & $t^{22}$ & $p^{16}, s^{18}, z^{22}, y^{17}$ & $16,17,18,22$ \\
\hline Diptera n.d. & & $+^{21}$ & & $\mathrm{v}^{21}$ & 21 \\
\hline \multicolumn{6}{|l|}{ Polychaeta } \\
\hline Polychaeta n.d. & $+^{18}$ & $\boldsymbol{+}^{17,19,20,21}$ & $++^{22}$ & $s^{18}, t^{19}, u^{20}, v^{21}, z^{22}, y^{17}$ & $17,18,19,20,21,22$ \\
\hline \multicolumn{6}{|l|}{ Oligocheta } \\
\hline Oligocheta n.d. & $+^{18}$ & & & $\mathrm{~s}^{18}$ & 18 \\
\hline \multicolumn{6}{|l|}{ Pisces } \\
\hline Eggs & $\boldsymbol{t}^{18}$ & & & $s^{18}$ & 18 \\
\hline Gobiidae & & & $+^{22}$ & $\mathrm{z}^{22}$ & 22 \\
\hline Pisces n.d. & $+^{18}$ & $\boldsymbol{+}^{17,20,21}$ & $+22,23 \mathrm{p}$ & $\mathrm{s}^{18}, \mathrm{u}^{20}, \mathrm{v}^{21}, \mathrm{z}^{22}, \mathrm{x}^{23}, \mathrm{y}^{17}$ & $17,18,20,21,22,23$ \\
\hline
\end{tabular}


bighead and round goby diets did not overlap in spring, but significantly overlapped in summer and autumn (Borza et al., 2009). Beside this, an overlap in individual dietary items varies by season (Števove and Kovăč, 2013; Brandner et al., 2013), which could be the reason for different results. High values of dietary overlap were found between round goby and bighead goby in the middle Danube (Copp et al., 2008) and the lower Rhine (Borcherding et al., 2013), indicating high levels of interspecific competition on food resources. Also, in the same river in Slovakia, round goby and bighead goby showed a significant overlap with perch Perca fluviatilis and Balon's ruffe Gymnocephalus baloni in their diet (Copp et al., 2008). In the Baltic Sea, the diet of round goby and European flounder Platichthys flesus overlapped (Karlson et al., 2007).

In the Danube Delta in Romania, the diet of monkey goby and white bream Blicca bjoerkna, stellate tadpolegoby Benthophilus stellatus, as well as striped ruffe Gymnocephalus schraetser overlapped (Sindilariu and Freyhof, 2003).

\section{AGE AND GROWTH}

Scale analysis of monkey goby in Lake Manyas (Sasi and Berber, 2010) and the River Ipel' (Plachá et al., 2010) and bighead goby in the rivers Sava (Simonović, 1996) and Danube (Copp et al., 2008) demonstrated five different age groups. Furthermore, the analysis of scales in round goby in the Danube showed four age groups (Grul'a et al., 2012). Moreover, by analysing the otoliths of round goby in the Baltic Sea (Sokołovska and Fey, 2011) and the Great Lakes (Huo et al., 2014), five and six age groups were found, respectively. Lower growth of P-C gobies in invaded freshwater areas of Europe may not surprisingly be due to their lower growth in their native freshwater habitat (Corkum et al., 2004). Thus, round goby in the southern Baltic Sea is reported to have a longer life span (up to 6 years) and larger size at age than most round goby populations (Sokołowska \& Fey, 2011), further suggesting larger sizes in saline water (Kornis et al., 2012). The introduced round goby exhibits its sexual maturity at a smaller length and age groups than the majority of native populations (Maclnnis and Corkum, 2000a, 2000b; L'avrinčíková and Kováč, 2007), and the same is valid for bighead goby (Kováč et al., 2009).

The authors who studied the scales of monkey goby (Plachá et al., 2010) and round goby (Grul'a et al., 2012) showed the unreliability of the von Bertalanffy growth model (Table 2 ). In both cases, the reason for that was in the breaking of confidence limits by $95 \%$ of calculated growth parameters. However, it is possible that the annuli on the scales are imprecisely determined (Britton et al., 2004), that this model describes well the somatic growth only after sexual maturity (Lester et al., 2004) and that it does not contain a variable of water temperature which affects physiological processes while determining growth (Kielbassa et al., 2010). In contrast to previous considerations, Sasi and Berber (2010) found five age groups for monkey goby in Lake Manyas in Turkey and by using the von Bertalanffy model they managed to measure von Bertalanffy growth parameters. The same model was successfully applied by Maclnnis (1997) and Huo et al. (2014) who studied the otoliths of round gobies from Lake Michigan.

Due to lack of research on bighead goby, von Bertalanffy growth parameters only for monkey and round goby in native and non-native part of Europe are presented in Table 2.

\section{GENOTYPING}

The analysis of mitochondrial DNA cytochrome b haplotypes in monkey goby from the Black and the Caspian Sea Basin manifested the greatest genetic diversity among populations living in the Azov and the Caspian Sea, and the lowest among populations living in the European rivers, the Vistula

Table 2. Von Bertalanffy growth parameters, age and sex of monkey goby and round goby. The symbol * indicates the standard length, otherwise the total length is shown, while the symbol ** denotes counting annuli on the otoliths, otherwise annulus count on the scales is shown ( $\mathrm{M}=$ males; $F=$ females; $N=$ native; $A=$ non-native)

\begin{tabular}{|c|c|c|c|c|c|c|c|}
\hline Species & Age & $(\mathrm{cm})$ & $\left(\right.$ year $\left.^{-1}\right)$ & (year) & Sex & Distribution & References \\
\hline \multirow{3}{*}{$\begin{array}{l}\text { Monkey } \\
\text { goby }\end{array}$} & - & 14.70 & 0.42 & & & $\mathrm{~N}$ & Froese and Pauly, 2015 \\
\hline & $\mathrm{I}-\mathrm{V}$ & 22.89 & 0.489 & -1.390 & $M+F$ & A & Sasi and Berber, 2010 \\
\hline & $\begin{array}{l}\mathrm{I}-\mathrm{IV} \\
\mathrm{I}-\mathrm{V}\end{array}$ & $\begin{array}{c}8.037 \\
11.129\end{array}$ & $\begin{array}{l}0.30 \\
0.23\end{array}$ & $\begin{array}{l}-0.95 \\
-0.77\end{array}$ & $\begin{array}{l}\mathrm{F} \\
\mathrm{M}\end{array}$ & A & Plachá et al., 2010 * \\
\hline \multirow{4}{*}{$\begin{array}{l}\text { Round } \\
\text { goby }\end{array}$} & I - IV & $\begin{array}{c}12.35 \pm 2.38 \\
23.69 \pm 10.54\end{array}$ & $\begin{array}{l}0.24 \pm 0.10 \\
0.11 \pm 0.07\end{array}$ & $\begin{array}{l}-1.06 \pm 0.38 \\
-0.95 \pm 0.30\end{array}$ & $\begin{array}{l}\mathrm{F} \\
\mathrm{M}\end{array}$ & A & Grul'a et al., 2012 * \\
\hline & II - VII & $\begin{array}{l}13.285 \pm 0.943 \\
18.447 \pm 2.375\end{array}$ & $\begin{array}{l}0.263 \pm 0.037 \\
0.162 \pm 0.032\end{array}$ & $\begin{array}{l}-0.275 \pm 0.087 \\
-0.144 \pm 0.086\end{array}$ & $\begin{array}{l}\mathrm{F} \\
\mathrm{M}\end{array}$ & A & Huo et al., $2014 * *$ \\
\hline & - & $\begin{array}{l}13.30 \\
21.90\end{array}$ & $\begin{array}{l}0.35 \\
0.11\end{array}$ & $\begin{array}{l}-0.21 \\
-1.62\end{array}$ & $\begin{array}{c}M \\
F\end{array}$ & $\mathrm{~N}$ & Froese and Pauly, 2015 \\
\hline & I - III & $10.18 \pm 3.84$ & $0.61 \pm 0.51$ & $0.28 \pm 0.23$ & $M+F$ & A & Maclnnis, $1997 * * *$ \\
\hline
\end{tabular}


and Hron (Neilson and Stepien, 2011). Study of the cytochrome $b$ gene and microsatellites of round gobies by Stepien and Tumeo (2006) demonstrated the greatest genetic diversity among populations living in the Black Sea and the Great Lakes, and the lowest among European freshwater populations. However, Brown and Stepien (2008) reported that in many locations in the Black, Caspian, Azov and Baltic Sea, and the Danube, Dnieper, Moscow and Volga, genetic diversity was higher among the native than among the introduced populations. For the individuals from the upper Danube flow, the most common Black Sea haplotype 1 was determined and genetic diversity was low (Table 3; Cerwenka et al., 2014). However, in the introduced populations of the River Rhine Basin in Germany (Cerwenka et al., 2014) and Belgium (Table 3; Mombartes et al., 2014), a relatively high level of genetic diversity was demonstrated. It was assumed that it occurred due to the geopolitical changes in the 1990s; namely, at the time ship traffic was eight times higher in the River Rhine Basin than in the Danube due to the collapse of the Communist government and the Croatian War of Independence (Roche et al., 2013). By analysing the non-coding control region of round gobies, Stepien et al. (2005) reported that the North American populations have a greater genetic diversity than the native Eurasian populations. Also, by analysing the control region sequences of round goby, Dillon and Stepien (2001) found a relatively high genetic diversity in the introduced populations of the Great Lakes of North America, the Gulf of Gdansk in Poland and the native populations of the Black Sea.

Genetic diversity was similar for native and introduced populations, which suggested numerous populations that were found and the absence of a bottleneck. The reason for these diverse results could be found in continuous intake of individuals which enables the transfer of genes between populations (LaRue et al., 2011). Besides, noncoding control region has a higher level of genetic diversity than cytochrome b gene (Stepien and Kocher, 1997). The research on microsatellites of round gobies and bighead goby from the Danube in Slovakia showed a low to moderate genetic diversity, i.e. limited polymorphism as a result of founder effect (Vyskočilová et al., 2007). Furthermore, the same level of genetic diversity was found between the native Black Sea and introduced Eurasian or North American round goby populations (Feldheim et al. 2009). As shown for microsatellites of round goby from Lake Michigan, a correlation between geographic distance and genetic diversity was not found, but it was found between the amount of ship traffic and genetic diversity (LaRue et al., 2011). Moreover, by analysing microsatellites of round goby in the Baltic Sea, Björklund and Almqvist (2010) found the greatest genetic diversity just between locations with the most different habitats.

Table 3. Cytochrome $b$ haplotypes and sampling locations for monkey goby, round goby and bighead goby ( $N=$ native; $I=$ invasive)

\begin{tabular}{|c|c|c|c|c|}
\hline Species & Haplotype designation & Sampling location & Distribution & References \\
\hline \multirow{19}{*}{$\begin{array}{l}\text { Monkey } \\
\text { goby }\end{array}$} & haplotype 1 & Vistula Poland, Hron Slovakia & I & \multirow{12}{*}{$\begin{array}{l}\text { Neilson and } \\
\text { Stepien, } 2011\end{array}$} \\
\hline & haplotype 1 & Ozero Manych, Tsimlyanska Reservoir, Russia & $\mathrm{N}$ & \\
\hline & haplotype 2 & Rioni River Georgia, Tyligul Estuary Ukraine & $\mathrm{N}$ & \\
\hline & haplotype 3 & $\begin{array}{l}\text { Dniester, Dnieper, Khadzhibey Estuary Ukraine, } \\
\text { Chagraiskoye Reservoir Russia }\end{array}$ & $\mathrm{N}$ & \\
\hline & haplotype 4 & Azov Sea, Ukraine & $\mathrm{N}$ & \\
\hline & haplotype 5 & Lake Sarpa, Chernozemel'skii Connector, Russia & $\mathrm{N}$ & \\
\hline & haplotype 6 & Danube, Ukraine & $\mathrm{N}$ & \\
\hline & haplotype 7 & Dniester delta, Ukraine & $\mathrm{N}$ & \\
\hline & haplotype 11 & Dniester, Ukraine & $\mathrm{N}$ & \\
\hline & haplotype 37- 99 & Caspian Sea, Volga delta & $\mathrm{N}$ & \\
\hline & haplotype 1-36, 100-107 & Black Sea, Volga, Don & $\mathrm{N}$ & \\
\hline & ALL13 & Volga, Russia & $\mathrm{N}$ & \\
\hline & ANT5 & Ozero Manych, Russia & $\mathrm{N}$ & \multirow{4}{*}{$\begin{array}{l}\text { Neilson and } \\
\text { Stepien, 2009b }\end{array}$} \\
\hline & AGV7 & Danube, Ukraine & 1 & \\
\hline & AGV9 & Azov Sea, Ukraine & $\mathrm{N}$ & \\
\hline & ANG11 & Chernozemelskii Chann., Russia & $\mathrm{N}$ & \\
\hline & FJ526752 & Don, Ukraine & $\mathrm{N}$ & \multirow{3}{*}{$\begin{array}{l}\text { Medvedev et } \\
\text { al., } 2013\end{array}$} \\
\hline & $\mathrm{Nf1}, \mathrm{Nf3}, \mathrm{GQ} 444338$ & Lake Sasyk, Ukraine & $\mathrm{N}$ & \\
\hline & Nf2, GQ444372 & Caspian Sea, Volga Delta & $\mathrm{N}$ & \\
\hline
\end{tabular}


Table 3. Continued

\begin{tabular}{|c|c|c|c|c|}
\hline & ame1 & Baltic Sea, Poland & 1 & \\
\hline & ame1, 23 & Danube, Slovakia & 1 & \\
\hline & ame1, 7 & Danube, Serbia & 1 & \\
\hline & $\begin{array}{l}\text { ame1, } 10,11,62,65,67,68 \\
77,78,79\end{array}$ & Black Sea, Bulgaria & $\mathrm{N}$ & \\
\hline & $\begin{array}{l}\text { ame } 1-10,18,48,60-66,69 \\
74-76,80\end{array}$ & Black Sea, Ukraine & $\mathrm{N}$ & \\
\hline & $\begin{array}{l}\text { ame } 1,18,49,50,51,58,72, \\
73\end{array}$ & Bug, Ukraine & $\mathrm{N}$ & \\
\hline & ame $1,7,8,57$ & Dnieper, Ukraine & $\mathrm{N}$ & Brown and \\
\hline & ame $1,58,59$ & Dnieper, Ukraine & 1 & Stepien, 2008 \\
\hline & ame $18,41-48$ & Kerch Strait, Ukraine & $\mathrm{N}$ & \\
\hline & ame $11-19$ & Azov Sea & $\mathrm{N}$ & \\
\hline & ame $24-28$ & Moskva River, Russia & I & \\
\hline & ame 20 & Volga-Don Canal & 1 & \\
\hline & ame $20,24,25,29,30$ & Volga, Russia & 1 & \\
\hline & ame $20-22$ & Caspian Sea, Russia & $\mathrm{N}$ & \\
\hline Round goby & ame $31-33,35,70,71,81-85$ & Caspian Sea, Azerbaijan & $\mathrm{N}$ & \\
\hline & ame $31-40,86$ & Caspian Sea, Iran & $\mathrm{N}$ & \\
\hline & AKB1, APT1, ALK6 & Caspian Sea, Azerbaijan & $\mathrm{N}$ & \\
\hline & AHF8 & Black Sea, Ukraine & $\mathrm{N}$ & \\
\hline & APC8 & Kerch Strait, Ukraine & $\mathrm{N}$ & $\begin{array}{l}\text { Neilson and } \\
\text { Stepien, 2009b }\end{array}$ \\
\hline & AMP2 & Volga, Russia & 1 & \\
\hline & $\mathrm{AHC} 3$ & Dnieper, Ukraine & 1 & \\
\hline & Nm1, EU331215 & Chernaya River, Russia & $\mathrm{N}$ & \\
\hline & $\mathrm{Nm} 2$ & Lake Sasyk, Ukraine & $\mathrm{N}$ & \\
\hline & Nm3, EU331165 & Black Sea, Ukraine & $\mathrm{N}$ & al., 2013 \\
\hline & ame10 & Black Sea, Bulgaria, Ukraine & $\mathrm{N}$ & \\
\hline & ame $1-10$ & Dniester & $\mathrm{N}$ & \\
\hline & ame $41-48$ & Azov Sea & $\mathrm{N}$ & $\begin{array}{l}\text { Brown and } \\
\text { Stepien, } 2009\end{array}$ \\
\hline & ame $20-22,24-30$ & Volga & $\mathrm{N}$ & \\
\hline & haplotype 1 & Danube, Germany & 1 & $\begin{array}{l}\text { Cerwenka et } \\
\text { al., } 2014\end{array}$ \\
\hline & NSB1, NSB2, NSB3 & Rhine Basin, Belgium & 1 & $\begin{array}{l}\text { Mombaerts et } \\
\text { al., } 2014\end{array}$ \\
\hline & APT7 & Lake Simferopol, Ukraine & $\mathrm{N}$ & \\
\hline & APT8 & Danube, Serbia & 1 & $\begin{array}{l}\text { Neilson and } \\
\text { Stepien, 2009b }\end{array}$ \\
\hline & ALC2 & Dniester, Ukraine & $\mathrm{N}$ & \\
\hline Bighead & APT8 & Rhine, Switzerland & 1 & $\begin{array}{l}\text { Kalchhauser et } \\
\text { al., } 2014\end{array}$ \\
\hline & NkeAGV3 & Black Sea Basin & $\mathrm{N}$ & $\begin{array}{l}\text { Neilson and } \\
\text { Stepien, 2009a }\end{array}$ \\
\hline & Nk1, FJ526770 & Lake Sasyk, Ukraine & $\mathrm{N}$ & Medvedev et \\
\hline & Nk 2 & Danube, Ukraine & $\mathrm{N}$ & al., 2013 \\
\hline
\end{tabular}

The large number of haplotypes found outside their natural range (Table 3 ) suggests a relatively large number of introduced populations (Dillon and Stepien, 2001; Ağdamar et al., 2015), thus increasing the probability of their establishment and persistence (Stepien and Tumeo, 2006; Facon et al. 2008; Fitzpatrick et al. 2012), which consequently has the strength of their invasive potential (Simonović et al., 2013; Piria et al., 2016a). 


\section{IMPACT ON NATIVE FISH SPECIES}

Most concern for the impact of P-C gobies in newly invaded areas is focused on native protected species. Such possible negative impact on the protected fish species zingel Zingel zingel by bighead and round goby in Croatia (Piria et al. 2016b) and by bighead goby in Slovakia was reported (Adámek et al., 2007). Also, a negative impact on abundance of zander Stizostedion lucioperca by bighead goby (Adámek et al., 2007), bullhead Cottus gobio, stone loach Barbatula barbatula and white-finned gudgeon Gobio albipinnatus by bighead goby (Jurajda et al., 2005), chub Squalius cephalus by round and bighead goby (Piria et al., 2016b) and a decline in the ratio of gudgeon Gobio gobio (Jakovlić et al., 2015) were noted. Also, the possibility of competition for food between P-C gobies and Eurasian perch Perca fluviatilis, as well as Balon's ruffe Gymnocephalus baloni, has been proposed (Copp et al., 2008). Contrary to these findings, several researches reveal positive impact of $\mathrm{P}-\mathrm{C}$ gobies on cod Gadus morhua, perch (Almqvist et al., 2010), burbot Lota lota (Corkum et al., 2004), catfish Silurus glanis and zander populations (Lenhardt et al., 2011) as their prey. Moreover, an increasing trend in abundance of Balkan golden loach Sabanejewia balcanica in response to round goby, as well as of crucian carp Carassius carassius, Balkan loach Cobitis elongata and burbot in response to the presence of monkey goby, were noted (Piria et al., 2016b).

In laboratory studies, Chotkowski and Marsden (1999) reported that round goby fed on eggs and fry of lake trout Salvelinus namaycush, and eggs of lake sturgeon Acipenser fluvescens, reducing the hatching of these species. In the St Clair River, Janssen and Jude (2001) indicated that recruitment failure of mottled sculpins Cottus bairdi resulted from spawning interference by round goby, while Dubs and Corkum (1996) predicted that round goby would induce mottled sculpins to desert nearshore habitats and be forced into deeper habitats where sculpins would be more susceptible to large predators.

\section{CONCLUSION}

Based on the gut content analyses, depending on the season, life stage, habitat and food availability, all three $\mathrm{P}-\mathrm{C}$ gobies partake different kind of invertebrates in native and non-native territory. In an area invaded by PontoCaspian species, positive diet selection of $\mathrm{P}-\mathrm{C}$ gobies on $\mathrm{P}-\mathrm{C}$ invertebrates was found. Also, based on the fact that several top predators feed on them, it could be assumed that they have found a specific role in the ecological niche of new invaded area. Impact of P-C gobies on endemic, rare or protected species still can be only speculative, but possible consequences can not be excluded. Presented age and growth results suggest that growth rates are highly variable and site specific. This can lead to a statistically unreliable von Bertalanffy model for P-C gobies and the necessity of testing other growth models. The combination of DNA variation and risk assessment procedures offers an important diagnostic and monitoring tool for evaluating the relative success of invasive species.

\section{ACKNOWLEDGEMENTS}

This study was supported by the Ministry of Agriculture, Directorate for Fisheries, Republic of Croatia and the University of Zagreb, Faculty of Agriculture.

\section{Sažetak}

\section{PREGLED EKOLOŠKIH I GENETSKIH ISTRAŽIVANJA PONTO-KASPIJSKIH GLAVOČA (Pisces, Gobiidae) U EUROPI}

Invazivni ponto-kaspijski glavoči riječni glavočić Neogobius fluviatilis, glavočić okrugljak Neogobius melanostomus i Keslerov glavočić Ponticola kessleri nedavno su uzrokovali dramatične promjene struktura ribljih zajednica diljem europskih riječnih sustava. Ovaj rad daje pregled novijih istraživanja o njihovim prehrambenim navikama, dobnoj strukturi i rastu, filogenetskim linijama igenetskoj raznolikosti. Osnovna hrana svih triju vrsta su beskralježnjaci,nešto rjeđe ribe, što ovisi o vrsti staništa, dobu godine, kao i morfološkim karakteristikama vrste. Prema von Bertalanffyjevu modelu rasta, veličina i starost je specifična za područje, ali zbog njegovih nedostataka potrebno je testirati i druge modele rasta. Filogenetske analize riječnog glavočića i glavočića okrugljaka ukazuje razdvajanje između haplotipova Crnog i Kaspijskog mora. Najveća genska raznolikost je pronađena među populacijama Crnog mora, a najniža među europskim invazivnim populacijama. Nedostatak molekularnih istraživanja Keslerova glavočića zahtijeva daljnja istraživanja.

Ključne riječi: europski riječni sistem, invazivni glavoči, ekologija, genetika

\section{REFERENCES}

Adámek, Z., Andreji, J., Gallardo, J. M. (2007): Food Habits of Four Bottom-Dwelling Gobiid Species at the Confluence of the Danube and Hron Rivers (South Slovakia). International Review of Hydrobiology, 92, 554-563.

Ağdamar, S., Tarkan, A. S., Keskin, E., Top, N., Doğaç, E., Baysal, Ö., Emiroğlu, Ö. (2015): The role of environmental factors and genetic diversity on colonization success of a non-native fish, Lepomis gibbosus from western part of Turkey. Biochemical Systematics and Ecology, 58, 195203.

Almqvist, G., Strandmark, A.K., Appelberg, M. (2010): Has the invasive round goby caused new links in Baltic food webs? Environmental Biology of Fishes, 89, 79-93. 
Ahnelt, H., Bănărescu, P., Spolwind, R., Harka, Á., Waidbacher, H. (1998): Occurrence and distribution of three Gobiid species (Pisces: Gobiidae) in the middle and upper Danube region - example of different dispersal patterns?. Biologia Bratislava, 53, 665-678.

Azour, F. (2011): Fødebiologi hos den sortmundede kulting Neogobius melanostomus I danske farvande. Copenhagen: Biologistuderende ved Københavns Universitet, http://snm.ku.dk/forskning/projekter/fiskeatlas/billeder/Sortmundet_kutlings_f_debiologi_i_DK.pdf/ (download: May 30 ${ }^{\text {th }}, 2012$ ) (In Danish)

Bănărescu, P. (1970): Die fische des Ponto-Kaspischen potamophilen Artenkomplexes und die Karpato-Kaukasische Disjunction. Hydrobioligia, 11, 3-24. (In German)

Bănaru, D., Harmelin-Vivien, M. (2009): Feeding behaviour of Black Sea bottom fishes: did it change over time?. Acta oecologica, 35, 769-777.

Bonacci O, Trninić D, Roje-Bonacci T (2008) Analysis of the water temperature regime of the Danube and its tributaries in Croatia. Hydrological Processes, 22, 1014-1021.

Björklund, M., Almqvist, G. (2010): Rapid spatial genetic differentiation in an invasive species, the round goby Neogobius melanostomus in the Baltic Sea. Biological Invasions, 12, 2609-2618.

Bogut, I., Novoselić, D., Pavličević, J. (2006): Biologija riba. Poljoprivredni fakultet, Osijek, 620 pp. (In Croatian)

Borcherding, J., Staas, S., Krüger, S., Ondračkovă, M., Šlapanský, L., Jurajda, P. (2011): Non-native Gobiid species in the lower River Rhine (Germany): recent range extensions and densities. Journal of Applied Ichthyology, 27, 153-155.

Borcherding, J., Dolina, M., Heermann, L., Knutzen, P., Krüger, S., Matern, S., van Treeck, R., Gertzen, S. (2013): Feeding and niche differentiation in three invasive gobies in the Lower Rhine, Germany. Limnologica, 43, 49-58.

Borza, P., Erős, T., Oertel, N. (2009): Food Resource Partitioning between Two Invasive Gobiid Species (Pisces, Gobiidae) in the Littoral Zone of the River Danube, Hungary. International Review of Hydrobiology, 94, 609-621.

Brandner, J., Auerswald, K., Cerwenka, A.F., Schliewen, U.K., Geist, J. (2013): Comparative feeding ecology of invasive Ponto-Caspian gobies. Hydrobiologia, 703, 113-131.

Britton, J. R., Cowx, I. G., Peirson, G. (2004): Management and Ecological Note Sources of error in the ageing of stocked cyprinids. Fisheries Management and Ecology, 11, 415-417.

Brown, J. E., Stepien, C. A. (2008): Ancient division, recent expansions: phylogeography and population genetics of the round goby Apollonia melanostoma. Molecular Ecology, 17, 2598-2615.

Brown, J. E., Stepien, C. A. (2009): Invasion genetics of the Eurasian round goby in North America: tracing sources and spread patterns. Molecular Ecology, 18, 64-79.

Cerwenka, A. F., Brandner, J., Geist, J., Schliewen, K. (2014): Strong versus weak population genetic differentiation af- ter a recent invasion of gobiid fishes (Neogobius melanostomus and Ponticola kess/eri) in the upper Danube. Aquatic Invasions, 9, 71-86.

Chotkowski, M. A., Marsden, J. E. (1999): Round goby and mottled sculpin predation on trout eggs and fry: field predictions from laboratory experiments. Journal of Great Lakes Research, 25, 26-35.

Copp, G. H., Bianco, P. G., Bogutskaya, N. G., Erös, T., Falka, I., Ferreira, M. T., Fox, M. G., Freyhof, J., Golzan, R. E., Grabowska, J., Kováč, V., Moreno-Amich, R., Naseka, A. M., Peňăz, M., Povž, M., Przybylski, M., Robillard, M., Russell, I. C., Stakènas, S., Šumer, S., Vila-Gispert, A., Wiesner, C. (2005): To be, or not to be, a non-native freshwater fish? Journal of Applied Ichthyology, 21, 242-262.

Copp, G. H., Kováč, V., Zweimüller, I., Dias, A., Nascimento, M., Balážová, M. (2008): Preliminary study of dietary interactions between invading Ponto-Caspian gobies and some native fish species in the River Danube near Bratislava (Slovakia). Aquatic Invasions, 3, 189-196.

Corkum, L. D., Sapota, M. R., Skora, K. E. (2004): The round goby, Neogobius melanostomus, a fish invader on both sides of the Atlantic Ocean. Biological Invasions, 6, 173181.

Čăpová, M., Zlatnickă, I., Kovač, V., Katina, S. (2008): Ontogenetic variability in the external morphology of monkey goby, Neogobius fluviatilis (Pallas, 1814) and its relevance to invasion potential. Hydrobiologia, 607, 17-26.

Ćaleta, M. (2007): Ekološke značajke intiofaune nizinskog dijela rijeke Save (Ecological characteristic of the ichthyofauna of the Sava River lowlands). PhD Thesis, Faculty of Science, University of Zagreb, $232 \mathrm{pp}$.

Diggins, T. P., Kauer, J., Chakraborti, R. K., DePinto, J. V. (2002): Diet choice by the exotic round goby (Neogobius melanostomus) as influenced by prey motillity and environmental complexity. Journal of Great Lakes Research, 28, 411-420.

Dillon, A. K., Stepien, C. A. (2001): Genetic and Biogeographic Relationships of the Invasive Round (Neogobius melanostomus) and Tubenose (Proterorhinus marmoratus) Gobies in the Great Lakes Versus Eurasian Populations. Journal of Great Lakes Research, 27, 267-280.

Dubs, D. O. L., Corkum, L. D. (1996): Behavioral interactions between round gobies (Neogobius melanostomus) and mottled sculpins (Cottus bairdi). Journal of Great Lakes Research, 22, 838-844.

Erős, T., Sevcsik, A., Tóth, B. (2005): Abundance and nighttime habitat use patterns of Ponto-Caspian gobiid species (Pisces, Gobiidae) in the littoral zone of the River Danube, Hungary. Journal of Applied Ichthyology, 21, 350-357.

Facon, B., Pointier, J. P., Jarne, P., Sarda, V., David, P. (2008): High genetic variance in life-history strategies within invasive populations by way of multiple introductions. Current Biology, 18, 363-367.

Feldheim, K. A., Willink, P., Brown, J. E., Murphy, D. J., Neil- 
son, M. E., Stepien, C. A. (2009): Microsatellite loci for Ponto-Caspian gobies: markers for assessing exotic invasions. Molecular Ecology Resources, 9, 639-644.

Fitzpatrick, B. M., Fordyce, J. A., Niemiller, M. L., Reynolds, R. G. (2012): What can DNA tell us about biological invasions? Biological Invasions, 14, 245-253.

Froese, R. and D. Pauly. Editors. (2015): FishBase. World Wide Web electronic publication. www. Fishbase.org, version (10/2015).

Grabowska, J., Grabowski, M., Kostecka, A. (2009): Diet and feeding habits of monkey goby (Neogobius fluviatilis) in a newly invaded area. Biological Invasions, 11, 2161-2170.

Grul'a, D., Balážová, M., Copp Gordon, H., Kovăč, V. (2012): Age and growth of invasive round goby Neogobius melanostomus from middle Danube. Central European Journal of Biology, 7, 448-459.

Harka, Á., Bíró, P. (2007): New patterns in Danubian distribution of Ponto-Caspian gobies - a result of global climatic change and/or climatization? Electronic Journal of Ichthyology, 1, 1-14.

Huo, B., Madenjian, C.P., Xie, C.X., Zhao, Y., O'Brien, T.P., Czesny, S.J. (2014): Age and growth of round gobies in Lake Michigan, with preliminary mortality estimation. Journal of Great Lakes Research, 4C: 4, 5, 6.

Jakovlič, I., Piria, M., Šprem, N., Tomljanović, T., Matulić, D., Treer, T. (2015): Distribution, abundance and condition of invasive Ponto-Caspian gobies Ponticola kessleri (Günther, 1861), Neogobius fluviatilis (Pallas, 1814), and Neogobius melanostomus (Pallas, 1814) in the Sava River basin, Croatia. Journal of Applied Ichthyology, 1-7.

Janssen, J., Jude, D. J. (2001): Recruitment failure of mottled sculpin Cottus bairdi in Calumet Harbor, southern Lake Michigan, induced by the newly introduced round goby Neogobius melanostomus. Journal of Great Lakes Research, 27, 319-328.

Jazdzewski, K., Konopacka, A. (2002): Invasive Ponto-Caspian species in waters of the Vistula and Oder Basins and the Southern Baltic Sea, In: Leppäkoski, E., Gollasch, S., Olenin, S. (Eds.), Invasive Aquatic Species of Europe; Distribution, Impacts and Management. Springer, Netherlands, pp. 384-398.

Jurajda, P., Černý, J., Polačik, M., Valová, Z., Janáč, M., Blažek, R., Ondračková, M. (2005): The recent distribution and abundance of non-native Neogobius fishes in the Slovak section of the River Danube. Journal of Applied Ichthyology, 21, 319-323.

Kakareko, T., Żbikowski, J., Żytkowicz, J. (2005): Diet partitioning in summer of two syntopic neogobiids from two different habitats of the lower Vistula River, Poland. Journal of Applied Ichthyology, 21, 292-295.

Kalchhauser, I., Mutzner, P., Hirsch, P. E., Burkhardt-Holm, P. (2013): Arrival of round goby Neogobius melanostomus (Pallas, 1814) and bighead goby Ponticola kessleri (Günther, 1861) in the High Rhine (Switzerland). Biological Invasions, $2,79-83$.
Kalchhauser, I., Kutschera, V. E., Burkhardt-Holm, P. (2014): The complete mitochondrial genome of the invasive Ponto-Caspian goby Ponticola kessleri obtained from highthroughput sequencing using the Ion Torrent Personal Genome Machine. Mitochondrial DNA Part A, 20, 1-3.

Karlson, A. M. L., Almqvist, G., Skóra, K. E., Appelberg, M. (2007): Indications of competition between indigenous round goby and native flounder in the Baltic Sea. ICES Journal of Marine Science, 64, 479-486.

Kessel van, N., Dorenbosch, M., De Boer, M. R. M., Leuven, R. S. E. W., Van der Velde, G. (2011): Competition for shelter between four invasive gobiids and two native benthic fish species. Current Zoology, 57, 844-851.

Kielbassa, J., Delignette-Muller, M. L., Pont, D., Charles, S. (2010): Application of a temperature-dependent von Bertalanffy growth model to bullhead (Cottus gobio). Ecological Modelling, 221, 2475-2481.

Kocovsky, P. M., Tallman, J. A., Jude, D. J., Murphy, D. M., Brown, J. E., Stepien, C. A. (2011): Expansion of tubenose gobies Proterorhinus semilunaris into western Lake Erie and potential effects on native species. Biological Invasions, 13, 2775-2784.

Kornis, M. S., Mercado-Silva, N., Vander Zanden, M. J. (2012): Twenty years of invasion: a review of round goby Neogobius melanostomus biology, spread and ecological implications. Journal of Fish Biology, 80, 235-285.

Kottelat, M., Freyhof, J. (2007): Handbook of European Freshwater Fishes. Kottelat, Cornol, Switzerland and Freyhof, Berlin, Germany, 646 pp.

Kováč, V., Copp, G. H., Sousa, R. P. (2009): Life-history traits of invasive bighead goby Neogobius kessleri from the middle Danube with a reflection of who may win the goby competition. Journal of Applied Ichthyology, 25, 33-37.

Kovtun, I. F., Nekrasova, M. R., Revina, N. I. (1974): On the diet of round goby (Neogobius melanostomus) and utilization of food supply in Azov Sea. Russian Journal of Zoology, 53, 728-736. (in Russian with English summary)

Kuhns, L.A., Berg, M.B. (1999): Benthic Invertebrate Community Responses to Round Goby (Neogobius melanostomus) and Zebra Mussel (Dreissena polymorpha) Invasion in Southern Lake Michigan. Journal of Great Lakes Research, 25, 910-917.

LaRue, E. A., Ruetz III, C. R., Stacey, M. B., Thum, R. A. (2011): Population genetic structure of the round goby in Lake Michigan: implications for dispersal of invasive species. Hydrobiologia, 663, 71-82.

L'avrinčíková, M., Kováč, V. (2007): Invasive round goby Neogobius melanostomus from the Danube mature at small size. Journal of Applied Ichthyology, 23, 276-278.

Lenhardt, M., Markovic, G., Hegedis, A., Maletin, S., Cirkovic, M., Markovic, Z. (2011): Non-native and translocated fish species in Serbia and their impact on the native ichthyofauna. Reviews in Fish Biology and Fisheries, 21, 407421.

Lester, N. P., Shuter, B. J., Abrams, P. A. (2004): Interpreting 
the von Bertalanffy model of somatic growth in fishes: the cost of reproduction. Proceedings of the Royal Society of London, 271, 1625-1631.

Leuven, R. S. E. W., van der Velde, G., Baijens, I., Snijders, J., van der Zwart, C., Lenders, H. J. R., bij de Vaate, A. (2009): The river Rhine: a global highway for dispersal of aquatic invasive species. Biological Invasions, 11, 19892008.

Maclnnis, A. J. (1997): Aspects of the life history of the round goby, Neogobius melanostomus (Perciformes: Gobiidae), in the Detroit River (Ontario, Michigan). PhD Thesis, Scholarship at UWindsor, University of Windsor, $108 \mathrm{pp}$.

Maclnnis, A. J., Corkum, L. D. (2000a): Age and growth of round goby Neogobius melanostomus in the upper Detroit River. Transactions of the American Fisheries Society, 129, 852-858.

Maclnnis, A. J., Corkum, L. D. (2000b): Fecundity and Reproductive Season of the Round Goby Neogobius melanosomus in the Upper Detroit River. Transactions of the American Fisheries Society, 129, 136-144.

Manné, S., Poulet, N., Dembski, S. (2013): Colonisation of the Rhine basin by non-native gobiids: an update of the situation in France. Knowledge and Management of Aquatic Ecosystems, 411, 02.

Medvedev, D. A., Sorokin, P. A., Vasil'ev, V. P., Chernova, N. V., Vasil'eva, E. D. (2013): Reconstruction of Phylogenetic Relations of Ponto-Caspian Gobies (Gobiidae, Perciformes) Based on Mitochondrial Genome Variation and Some Problems of Their Taxonomy. Journal of Ichthyology, 53, 702-712.

Mombaerts, M., Verreycken, H., Volckaert, F. A. M., Huyse, T. (2014): The invasive round goby Neogobius melanostomus and tubenose goby Proterorhinus semilunaris: two introduction routes into Belgium. Aquatic Invasions, 9, 305-314.

Mustafić, P. (2005): Indeks biotičkog integriteta riblje zajednice velikih rijeka Hrvatske. (Indeks of biotic integrity of the fish community in the large Croatian rivers). PhD Thesis, Faculty of Science, University of Zagreb, $185 \mathrm{pp}$.

Neilson, M. E., Stepien, C. A. (2009a): Evolution and phylogeography of the tubenose goby genus Proterorhinus (Gobiidae: Teleostei): evidence for new cryptic species. Biological Journal of the Linnean Society, 96, 664-684.

Neilson, M. E., Stepien, C. A. (2009b): Escape from the Ponto-Caspian: Evolution and biogeography of an endemic goby species flock (Benthophilinae: Gobiidae: Teleostei). Molecular Phylogenetics and Evolution, 52, 84-102.

Neilson, M. E., Stepien, C. A. (2011): Historic speciation and recent colonization of Eurasian monkey gobies (Neogobius fluviatilis and $N$. pallasi) revealed by DNA sequences, microsatellites, and morphology. Diversity and Distributions, 17, 688-782.

Paunovič, M., Tomović, J., Kovačevič, S., Zorič, K., Žganec, K., Simič, V., Atanacković, A., Marković, A., Kračun, M., Hudina, S., Lajtner, J., Gottstein, S., Lucić, A. (2012): Macro- invertebrates of the Natural Substrate of the Sava River - preliminary results. Water Resources Management, 2, 32-39.

Pinchuk, V. I., Vasil'Eva, E. D., Vasil'Ev, V. P. (2003): Neogobius fluviatilis Kessler, 1875. In: Miller, P. J. (ed.), The Freshwater Fishes of Europe. Vol 8/I Mugilidae, Atherinidae, Atherionopsidae, Blennidae, Odontobutidae, Gobiidae 1., AULA-Verlag GmbH Wiebelsheim, Verlag für Wissenschaft und Forschung, Germany, 223-264 pp.

Piria, M., Treer, T., Tomljanovič, T., Šprem, N., Matulič, D., Aničić, I., Safner, R. (2011a): First record of monkey goby, Neogobius fluviatilis (Pallas, 1814) in the barbell zone of the Sava River, Croatia. Journal of Applied Ichthyology, 27, 1383-1384.

Piria, M., Šprem, N., Jakovlić, I., Tomljanović, T., Matulić, D., Treer, T., Aničić, I., Safner, R. (2011 b): First record of round goby, Neogobius melanostomus (Pallas, 1814) in the Sava River, Croatia. Aquatic Invasions, 6, 153-157.

Piria, M., Povž, M., Vilizzi, L., Zanella, D., Simonović, P., Copp, G. H. (2016a): Risk screening of non-native freshwater fishes in Croatia and Slovenia using the Fish Invasiveness Screening Kit. Fisheries Management and Ecology, 23, 21-31.

Piria, M., Jakšić, G., Jakovlić, I., Treer, T. (2016b): Dietary habits of invasive Ponto-Caspian gobies in the Croatian part of the Danube River basin and their potential impact on benthic fish communities. Science of the Total Environment, 540, 386-395.

Plachá, M., Balážová, M., Kováč, V., Katina, S. (2010): Age and growth of non-native monkey goby Neogobius fluviatilis (Teleostei, Gobiidae) in the River Ipel', Slovakia. Folia Zoologica, 59, 332-340.

Polačik, M., Trichkova, T., Janáč, M., Vassilev, M., Jurajda, P. (2008): The Ichthyofauna of the Shoreline Zone in the Longitudinal Profile of the Danube River, Bulgaria. Acta Zoologica Bulgarica, 60, 77-88.

Polačik, M., Janáč, M., Jurajda, P., Adámek, Z., Ondračková, M., Trichkova, T., Vassilev, M. (2009): Invasive gobies in the Danube: invasion success facilitated by availability and selection of superior food resources. Ecology of Freshwater Fish, 18, 640-649.

Polačik, M., Janáč, M., Vassilev, M., Trichkova, T. (2012): Morphometric comparison of native and non-native populations of round goby Neogobius melanostomus from the River Danube. Folia Zoologica, 61, 1-8.

Povž, M. (2016): Glavati kapič (Neogobius kessleri) - riba pritepenka. Ribič, 3, 45. (In Slovenian)

Ray, W.J., Corkum, L.D. (1997): Predation of zebra mussels by round gobies, Neogobius melanostomus. Environmental Biology of Fishes, 50, 267-273.

Roche, K. F., Janač, M., Jurajda, P. (2013): A review of Gobiid expansion along the Danube-Rhine corridor - geopolitical change as a driver for invasion. Knowledge and Management of Aquatic Ecosystems, 411, 01.

Sapota, M. R. (2004): The round goby (Neogobius melanos- 
tomus) in the Gulf of Gdansk - a species introduction into the Baltic Sea. Hydrobiologia, 514, 219-224.

Sasi, H., Berber, S. (2010): Some Biological Characteristics of Monkey Goby in Anatolia. Asian Journal of Animal and Veterinary Advances, 5, 229-233.

Seifert, K., Hartmann, F. (2000): The Kesslergrundel Neogobius kessleri (Günther 1861), a new species in the German Danube. Lauterbornia, 38, 105-108. (In German)

Simonović, P. D. (1996): Cranial osteology of the bighead goby Neogobius kessleri from the rivers Danube and Sava (Serbia, Yugoslavia). Italian Journal of Zoology, 63, 65-72.

Simonović, P., Valković, B., Paunović, M. (1998): Round goby Neogobius melanostomus, a new Ponto Caspian element for Yugoslavia. Folia Zoologica, 47, 305-312.

Simonović, P., Paunović, M., Popović, S. (2001): Morphology, Feeding, and Reproduction of the Round Goby, Neogobius melanostomus (Pallas), in the Danube River Basin, Yugoslavia. Journal of Great Lakes Research, 27, 281-289.

Simonovič, P., Tošić, A., Vassilev, M., Apostolou, A., Mrdak, D., Ristovska, M. (2013): Risk identification of non-native freshwater fishes in four countries of the Balkans Region using FISK. Mediterranean Marine Science, 14, 369-376.

Sindilariu, P.D., Freyhof, J. (2003): Food overlap of benthic fishes int he Danube Delta, with special respect to two invasive gobiids (Teleostei: Gobiidae, Percidae, Cyprinidae). Lauterbornia, 46, 149-157.

Skóra, K. E., Rzeznik, J. (2001): Observations on diet composition of Neogobius melanostomus Pallas 1811 (Gobiidae, Pisces) in the Gulf of Gdansk (Baltic Sea). Journal of Great Lakes Research, 27, 290-299.

Smirnov, A. I. (1986): Percifomes (Gobioidei), Scorpaeniformes, Pleuronectiformes, Lophiiformes. Fauna Ukraini, 8, 7-183.

Sokołovska, E., Fey, D. P. (2011): Age and growth of the round goby Neogobius melanostomus in the Gulf of Gdansk several years after invasion. Is the Baltic Sea a new Promised Land? Journal of Fish Biology, 78, 19932009.

Stepien, C. A., Kocher, T. D. (1997): Molecules and morphology in studies of fish evolution. In T. D. Kocher \& C. A. Stepien (Eds.) Molecular Systematics of Fishes (pp. 1-11). San Diego, CA: Academic Press.

Stepien, C. A., Brown, J. E., Neilson, M. E., Tumeo, M. A. (2005): Genetic Diversity of Invasive Species in the Great
Lakes Versus Their Eurasian Source Populations: Insights for Risk Analysis. Risk Analysis, 25, 1043-1060.

Stepien, C. A., Tumeo, M. A. (2006): Invasion genetics of Ponto-Caspian gobies in the Great Lakes: a 'cryptic' species, absence of founder effects, and comparative risk analysis. Biologial Invasions, 8, 61-78.

Svietovidov, A. N. (1964): Fishes of the Black Sea. Moscow, Soviet Academy of Sciences.

Števove, B., Kováč, V. (2013): Do invasive bighead goby Neogobius kessleri and round goby N. Melanostomus (Teleostei, Gobiidae) compete for food?. Knowledge and Management of Aquatic Ecosystems, 410, 08.

Vanderploeg, H. A., Nalepa, T. F., Jude, D. J., Mills, E. L., Holeck, K. T., Liebig, J. R., Grigorovich, I. A., Ojaveer, H. (2002): Dispersal and emerging ecological impacts of Ponto-Caspian species in the Laurentian Great Lakes. Canadian Journal of Fisheries and Aquatic Sciences, 59, 1209-1228.

Vassil'Ev, E. D., Vassil'Eva, V. P. (2003): Neogobius kessleri Günther, 1861. In: Miller, P. J. (ed.), The Freshwater Fishes of Europe. Vol 8/I Mugilidae, Atherinidae, Atherionopsidae, Blennidae, Odontobutidae, Gobiidae 1., AULA-Verlag GmbH Wiebelsheim, Verlag für Wissenschaft und Forschung, Germany, pp. 280-292.

Vassilev, M., Apostolou, A., Velkov, B., Dobrev, D., Zarev, V. (2012): Atlas of the gobies (Gobiidae) in Bulgaria. Institute of Biodiversity and Ecosystem Research, Bulgarian Academy of Sciences, Sofia, $112 \mathrm{pp}$.

Verreycken, H., Breine, J. J., Snoeks, J., Belpaire, C. (2011): First record of the round goby, Neogobius melanostomus (Actinopterygii: Perciformes: Gobiidae) in Belgium. Acta Ichthyologica Piscitoria, 41, 137-140.

Vutskits, G. Y. (1911): A new fish species of our fauna. Állattani Közlemények, pp. 31-34. (In Hungarian)

Vyskočilová, M., Ondračková, M., Šimková, A., Martin, J. F. (2007): Isolation and characterization of microsatellites in Neogobius kessleri (Perciformes, Gobiidae) and crossspecies amplification within the family Gobiidae. Molecular Ecology Notes, 7, 701-704.

Wiesner C (2005) New records of non-indigenous gobies (Neogobius sp.) in the Austrian Danube. Journal of Applied Ichthyology, 21, 324-327

Žganec, K., Gottstein, S., Hudina, S. (2009): Ponto-Caspian amphipods in Croatian large rivers. Aquatic Invasions, 4, 327-335. 